\title{
Student's Worksheet According to Problem Based Learning Reviewed from Understanding Mathematical Concept
}

\author{
Danuri $^{1, *}$, Nur Khoiru Nisa Hanifah ${ }^{2}$, Padrul Jana ${ }^{2}$, Romelan Hamzah ${ }^{3}$ \\ ${ }^{1}$ Department of Elementary School Teacher Education, Universitas PGRI Yogyakarta, Jl. PGRI 1 No. 117 Sonosewu, Bantul, \\ Yogyakarta, Indonesia \\ ${ }^{2}$ Department of Mathematics Education, Universitas PGRI Yogyakarta, Jl. PGRI 1 No. 117 Sonosewu, Bantul, Yogyakarta, Indonesia \\ ${ }^{3}$ Department of Mathematics Education, Universitas Ahmad Dahlan, Jl. Kapas No.9, Semaki, Kec. Umbulharjo, Kota Yogyakarta \\ 55166, Indonesia
}

Received July 14, 2020; Revised October 1, 2020; Accepted November 19, 2020

\section{Cite This Paper in the following Citation Styles}

(a): [1] Danuri, Nur Khoiru Nisa Hanifah, Padrul Jana, Romelan Hamzah, "Student's Worksheet According to Problem Based Learning Reviewed from Understanding Mathematical Concept," Universal Journal of Educational Research, Vol. 8, No. 12A, pp. 7233 - 7238, 2020. DOI: 10.13189/ujer.2020.082505.

(b): Danuri, Nur Khoiru Nisa Hanifah, Padrul Jana, Romelan Hamzah (2020). Student's Worksheet According to Problem Based Learning Reviewed from Understanding Mathematical Concept. Universal Journal of Educational Research, 8(12A), 7233 - 7238. DOI: 10.13189/ujer.2020.082505.

Copyright $\odot 2020$ by authors, all rights reserved. Authors agree that this article remains permanently open access under the terms of the Creative Commons Attribution License 4.0 International License

\begin{abstract}
Due to the limited Student Worksheets (SW) that are specific to the aspect of understanding concepts encourage the need for breakthroughs to develop them. This study aims to produce teaching materials as student worksheets with Problem Based Learning (PBL) on the understanding of mathematics concepts in grade VII students and describe the quality of SW based on aspects of validity, practicality, and effectiveness. The SW development model uses the ADDIE (Analysis, Design, Development, Implementation, and Evaluation). The SW that is developed must meet the following criteria: valid, practical, and effective. The results of the validity assessment of the material and media experts and the assessment of teachers in schools obtained an average score of 4.23 (maximum score of 5.0) with excellent criteria. The practicality aspect is stated based on the questionnaire of students' responses when learning takes place with an average score obtained at 3.30 (maximum score of 4.0) with a good category. Then, the effective criteria are shown from the results of the students' mathematical concept ability tests through the problem description, which consists of seven indicators of understanding mathematical concepts. Obtained a score of each indicator 64.5; 82.0; 75.0; 92.7; 86.4; 65.6; and 63.5 shows that each indicator has a good category above. So
\end{abstract}

based on the results of aspects of validity, practicality, and effectiveness shows that SW with PBL in terms of understanding mathematical concepts can be applied in students' learning at school. This SW is expected to have a positive contribution to improving students' understanding of mathematical concepts in school.

Keywords Student's Worksheet, Problem-based Learning Basis, Mathematical Concept Understanding Ability

\section{Introduction}

Mathematics is a fundamental lesson learned from kindergarten to bachelor [1]. According to [2], [3] mathematics is a discipline that has an abstract concept. Mathematics can also form the character of students' thinking into human beings who think creatively and independently. Besides that, mathematics has clear levels and rules, so to learn it is not enough by reading and memorizing but requires understanding the concept of thinking ability [4]. Learning mathematics is often felt difficult by students because of several factors; one of 
them is because students are not able to imagine mathematical material in real life. To be able to increase the low ability, alternative solutions that can be done are by confronting new problems in real life with students. Such learning is called Problem Based Learning (PBL). $\mathrm{PBL}$ is a learning approach, where problems given to students are related to real-life or in their daily lives [5], [6]. Problem-based learning is based on the principle that a student's learning process is aided by the combination of individual intellectual exploration and the ability to collaborate with others [7]. Thus, PBL is a means for students to be able to think critically, have the skills to solve problems in real life, so students can find their concepts. This PBL approach can be presented in a Student Worksheet (SW) because the nature of the SW can be developed according to the conditions and situations of learning activities to be encountered [8]. The worksheet usually contains instructions, steps to complete the task; the task in a worksheet must be clear what competencies will be achieved from the worksheet [9], [10]. Meanwhile, according to [11] Student Work Sheets are sheets containing assignments that must be done by students. Activity sheets are usually in the form of instructions, steps to complete a task. A task that is ordered in the worksheet must be clear about the basic competencies that will be achieved.

So far, the PBL-based worksheet, which can review the understanding of mathematical concepts, is still very minimal. So students are less accustomed to solving problems in everyday life and less able to understand mathematical concepts [12]. Yet, according to Permendiknas No.22 of 2006, some of the goals of mathematics learning are that students are able to understand concepts and solve problems. So it is necessary to develop PBL-based worksheets that can understand mathematical concepts. The worksheet developed in this study is a Problem Based Learning (PBL) based work where the steps presented in the worksheet are based on indicators of understanding mathematical concepts. Also, the worksheets that are developed are based on problems in real life, so it is expected that students can get used to solving problems in daily life. Based on these problems, researchers developed Problem Based Learning (PBL) based Student Worksheets. In PBL -based SW, the SW must contain a series of real-life problems related to the material to be studied. The advantage of the PBL-based worksheet is that it can provide an opportunity for each student to think critically in solving daily life problems both independently and in groups, then students can also understand the concept of the material clearly because students themselves build their understanding [9]. The formulation of the problem in this research is how the development of Problem Based Learning (PBL) based Student Worksheet s for VII grade students of SMP Mataram Kasihan on integer and fraction operations material in terms of understanding mathematical concepts with good qualifications in terms of validity, practicality, and effectiveness of SW.

\section{Materials and Methods}

In this study, there are several instruments used, among others, the expert material, media expert, and teacher validation sheets used for validity tests, student questionnaire responses for practicality tests. This step is also following [13], which states that the procedure is standard and becomes a measure in developing student worksheets. The same thing was explained by [14], who stated that the validator is also useful in validating the material and media being developed. Also, this study uses post-test questions that are arranged based on indicators of understanding concepts for effectiveness testing. The research and development steps in this research are ADDIE. According to [15], [16] "ADDIE is an acronym for Analysis, Design, Development or production, Implementation or Delivery, and Evaluation." The steps in ADDIE also refer to Analysis, Design, Development or production, Implementation or Delivery, and Evaluation [17], [18]. The stages in ADDIE are following this research because learning is taught based on problems and is equipped with learning steps following the 2013 Curriculum and questions in the form of solving real problems, which are expected to stimulate the empowerment of higher-order thinking skills in students [19]. Besides, ADDIE is a simple model that is easy to understand, so that it is suitable for the research being carried out [20]. In the analysis, the phase did need analysis, analysis curriculum and the selection of instructional materials will be developed. At the design stage, the SW will be created. In this stage, the title of SW is determined in making the SW outline to be developed according to the PBL basis. At the Development stage, product development is carried out in connection with the manufacturing and testing of products in the form of SW. The manufacturing stage means the process of making a product in the form of a worksheet from start to finish and is ready to use. Next in the Implementation stage is the stage of using the product that has been produced. After the product is developed and passes the testing stage, the worksheet is then used in learning to support learning outcomes. This stage takes place during the mathematics learning of integer and fraction operations for class VII of Mataram Kasihan Bantul Middle School. In the final stage, namely the Evaluation stage this stage is carried out as a determination of the quality of the product that has been produced. Determination of the quality of this product in terms of validity, practicality and effectiveness. Determination of the quality of worksheets developed based on data from the assessment of material expert lecturers, media experts and teachers to measure the validity of worksheets, student questionnaire responses to 
measure practicality of worksheets and student post-test results data are used to measure the effectiveness of worksheets. The flow chart in the research process is shown in Figure 1 below.

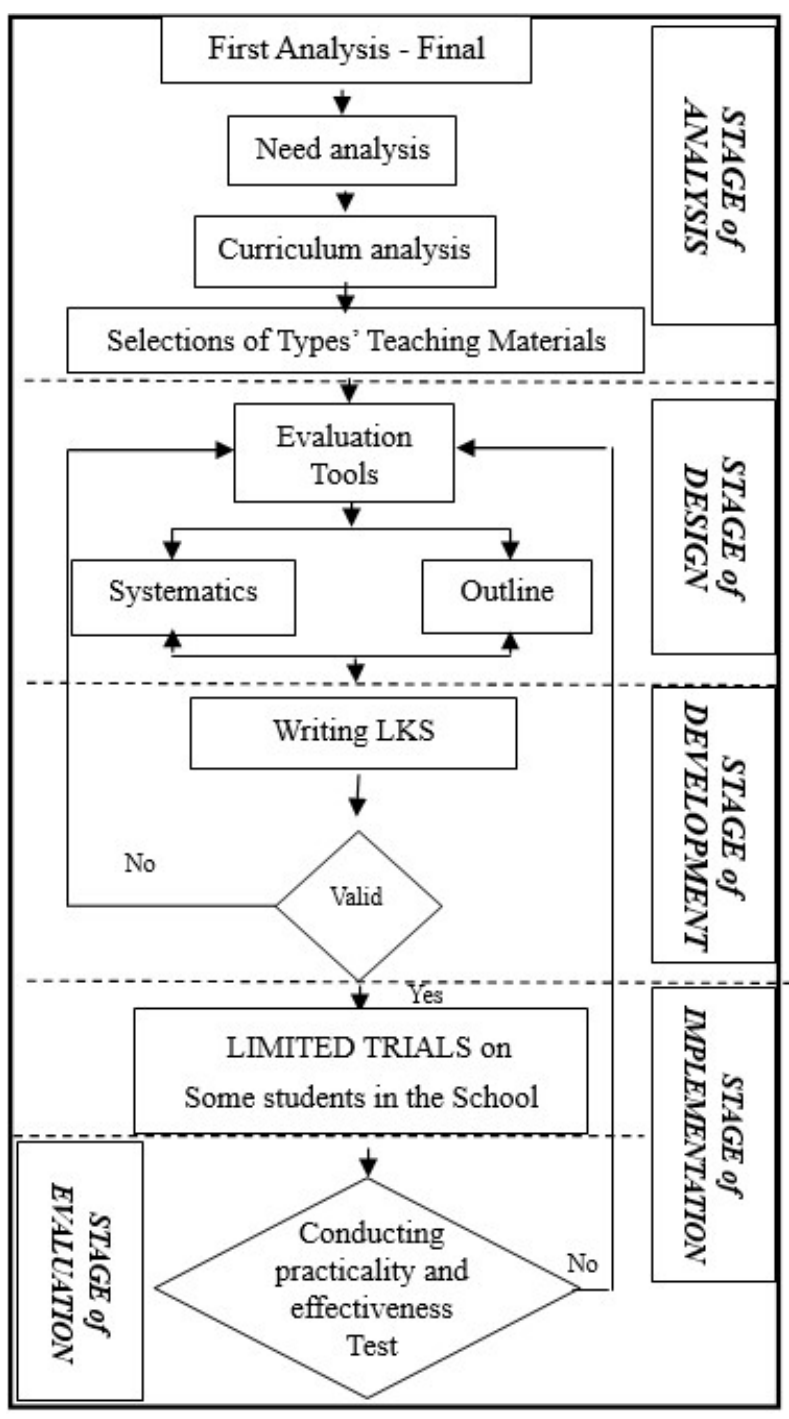

Figure 1. Research Flow Chart

\section{Result and Discussion}

\subsection{Result}

In the first stage, namely analysis. At this stage, the needs analysis and curriculum analysis are carried out. The results of the needs analysis that the researchers developed teaching materials in the form of Student Worksheet s (SW) based on Problem Based Learning (PBL) were reviewed based on the ability to understand mathematical concepts of Grade VII students of SMP Mataram Kasihan. And the result of the curriculum analysis obtained is that researchers develop PBL-based worksheets by referring to Basic Competencies (KD) 3.2 Explain and do integer and fraction operations by utilizing various operating properties and KD 3.4 Resolving problems related to integer count operations and fractions.

The second stage is the design. At this stage, reference collections, systematic SW, and SW outline compilation, and research instruments are arranged. At the reference, collection stage researchers look for some sources that are following the curriculum and also the material to be developed in the worksheet. Besides, researchers also added images sourced from personal documents to compile and complete the worksheet to be developed. The worksheet outline consists of three parts, namely the beginning, the core, and the end. SW is composed of several sections according to the material to be presented in the SW. The instruments used were SW assessment sheets, student response questionnaires, and post-test concept comprehension abilities.

The third stage is implementation. At this stage, the PBL-based SW-based activities were carried out with integer and fraction counting operations that had gone through the previous revision stage. SW is used by 32 students of class VII C of Mataram Kasihan Middle School with three meetings in the odd semester.

The final stage is the evaluation. At this stage, an analysis of the quality of Problem Based Learning (PBL) based SW is conducted by referring to validity, practicality, and effectiveness. The results of determining the quality of worksheets can be seen in the following table 1 .

Table 1. Results of Analysis of SW Assessment by Material Experts

\begin{tabular}{|c|c|c|}
\hline Aspect & Average & Criteria \\
\hline Format & 4.3 & Very decent \\
\hline Content & 4.3 & Very decent \\
\hline Language & 4.1 & Very decent \\
\hline
\end{tabular}

According to the table, 1 is data of SW validation by experts in the matter as obtained an average score of aspects of the format, content, and language are respectively 4.3; 4,3; and 4.1 with each aspect meets the minimum feasible criteria. The results of the assessment use a Likert scale with intervals of 1-5. The format aspect consists of 6 assessment items. The content aspect consists of 8 points of assessment, and the language aspect consists of 6 points of assessment. Prior to the assessment, several sections have been revised to adjust the material expert's advice. The parts that are fixed are the suitability of the indicators, the adjustment of the problems presented, and the use of language in describing the problem so that students can solve it. Of the three aspects obtained an average total score of 4.2 with very decent criteria

Table 2. Data on SW Assessment Results by Media Experts

\begin{tabular}{|c|c|c|}
\hline Aspect & Average & Criteria \\
\hline Linguistic & 4 & Worthy \\
\hline Graphical & 4.3 & Very decent \\
\hline
\end{tabular}


Based on table 2, the validation data obtained by media experts obtained an average score of linguistic and graphic aspects 4 and 4.3 , respectively, each meeting the minimum feasible criteria. The linguistic aspect consists of 5 assessment items, and the graphic consists of 10 assessment items. Before the assessment is carried out, it has first gone through the revision stage in the repair section on the cover layout, the suitability of the writing format, and the color combination used. From these two aspects, an average total score of 4.2 was obtained with very reasonable criteria.

Table 3. Data from SW Assessment Results by Master Mathematics

\begin{tabular}{|c|c|c|}
\hline Aspect & Average & Criteria \\
\hline Content eligibility & 4.0 & Worthy \\
\hline Language & 4.0 & Worthy \\
\hline Presentation & 4.1 & Very decent \\
\hline
\end{tabular}

Based on table 3, the results of the validation worksheet data by the mathematics teacher obtained an average score of aspects of content, language, and presentation successively as large as $4.0 ; 4.0 ; 4.1$. The content feasibility aspect consists of 13 assessment items, the linguistic aspect 14 assessment items, and the presentation aspect consists of 12 assessment items. Before the product is used by students, a revision is made to adjust the practice test questions to the students' abilities. This assessment is carried out by a mathematics teacher who is a grade VII teacher. Each aspect meets the minimum feasible criteria. From these three aspects, an average total score of 4 is obtained with a reasonable criterion. Based on tables 1, 2, and 3, it can be said that PBL-based SW meets valid criteria.

Table 4. Data Questionnaire Response Results

\begin{tabular}{|c|c|c|}
\hline Aspect & Average & Criteria \\
\hline Content eligibility & 3.27 & Well \\
\hline Presentation of material & 3.29 & Well \\
\hline Linguistic & 3.28 & Well \\
\hline Graphical & 3.16 & Well \\
\hline Total score & 13.0 & \\
\hline Total average & 3.25 & Well \\
\hline
\end{tabular}

Based on table 4, the student response questionnaire data above obtained an average score of aspects of content worthiness, presentation of material, linguistic and graphic succession of $3.27 ; 3.29 ; 3.28$ and 3.16 with each aspect meets the minimum criteria both. Unlike the previous ones, this assessment used a scale of 1-4. The number of each assessment item, namely in the content feasibility assessment, there were six assessment items, seven assessment items presented, three language assessment items, and six assessment items. Student responses are tested on all students in grade VII.

Table 5. Post Test Calculation Result Data

\begin{tabular}{|c|c|}
\hline Indicator & Average score \\
\hline Restate a concept & 64.5 \\
\hline $\begin{array}{c}\text { Classifying objects according to certain } \\
\text { properties (according to the concept) }\end{array}$ & 82.0 \\
\hline Give examples and no examples of a concept & 75.0 \\
\hline $\begin{array}{c}\text { Presenting concepts in various forms of } \\
\text { mathematical representation }\end{array}$ & 92.7 \\
\hline $\begin{array}{c}\text { Developing the necessary and sufficient } \\
\text { conditions of a concept }\end{array}$ & 86.4 \\
\hline $\begin{array}{c}\text { Use, utilize, and select certain procedures or } \\
\text { operations }\end{array}$ & 65.6 \\
\hline $\begin{array}{c}\text { Applying mathematical problem-solving } \\
\text { concepts and algorithms }\end{array}$ & 63.5 \\
\hline
\end{tabular}

From the results of the test of problem-solving abilities obtained, an average of each indicator is $64.5 ; 82.0$; 75.0; 92.7; 86.4; 65.6; and 63.5. At the same time, the overall indicator of overall understanding of the concept is 75.6. These results are consistent with a minimum of a concept understanding test qualification that is minimal good. By referring to the data obtained in tables 1-5, the Problem Based Learning (PBL) based worksheet can be said to meet valid, practical, and effective criteria.

\subsection{Discussion}

The purpose of this study is to develop Student Worksheet s (SW) based on problem-based learning on the ability of students to understand the concepts of Grade VII students. The quality of worksheets developed is based on three aspects, namely validity, practicality, and effectiveness.

The development procedure used is the ADIIE model. The stages of this model are analysis, design, development, implementation, and evaluation. The material developed in this study is the material for integer and fraction operations with competence. 3.2 Explain and perform integer and fraction operations using various operating properties and 4.2 Solve problems related to integer and fraction count operations.

The Student Worksheet that is developed can be stated to be of quality if it has fulfilled the rules of preparing the correct SW, namely valid, practical, and effective. The worksheets are compiled with ADDIE development procedures, and the worksheets are also arranged according to the basis of problem-based learning correctly, as explained earlier.

The assessment of experts stated the validity of the worksheet both materially and media. Material experts give an average score of 4.2, then media experts give an average score of 4.2, and mathematics teachers give an average score of 4 that meets the minimum criteria well. The results of the student response questionnaire obtained an average score of 3.25 in the good category so that the worksheet was declared practical. The concept comprehension ability 
test obtained the score of each indicator is 64.5 ; 82; 75; 92.7; 86.4; 65.6; and 63.5 that meet the minimum good category. At the same time, the percentage of mastery learning has a score of $78 \%$, which also meets the good category.

Quantitatively based on the description above, it can be concluded that the Student Worksheet (SW) based on problem-based learning (PBL) in terms of understanding the concept has been developed by the theory and meets the valid, practical, and effective criteria.

\section{Conclusions}

Any comments and suggestions are welcomed so that we can constantly improve this template to satisfy all authors' research needs.

Worksheets that have been developed based on Problem Based Learning (PBL) have fulfilled valid, practical, and effective criteria. Valid based on validity data with an average score of material experts 4.2; media expert 4.2; and mathematics teacher 4.0 with each category meeting the minimum criteria both. They are practically based on student response questionnaire data with an average score obtained of 3.25 in both categories. And for effective criteria based on post-test results data, the ability to understand mathematical concepts of students with an average score of each indicator of 64.5 ; 82.0; 75.0; 92.7; 86.4; 65.6; and 63.5, each indicator meets the minimum good category. Therefore PBL-based worksheets are viewed from the understanding of the mathematical concepts of Grade VII students of Mataram Kasihan Middle School on the material of integer and fraction operations considered to be suitable for use in mathematics learning.

\section{Acknowledgments}

We are very grateful to experts for their appropriate and constructive suggestions to improve this template.

1. Universitas PGRI Yogyakarta and LPPM have facilitated the authors to conduct and complete this research.

2. The principal of SMP Mataram Kasihan, Bantul Yogyakarta, gave the author permission and a place to carry out the research.

3. All those who helped in the writing process.

\section{REFERENCES}

[1] M. V Siagian, S. Saragih, and B. Sinaga, "Development of Learning Materials Oriented on Problem-Based Learning Model to Improve Students ' Mathematical Problem Solving Ability and Metacognition Ability,” Int. Electron. J. Math.
Educ., vol. 14, no. 2, pp. 331-340, 2019.

[2] S. Sanusi, E. Suprapto, and D. Apriandi, "Pengembangan Multimedia Interaktif sebagai Media Pembelajaran pada Pokok Bahasan Dimensi Tiga di Sekolah Menengah Atas (SMA)," J. Ilm. Pendidik. Mat. Vol, vol. 3, no. 2, pp. 398416, 2015.

[3] D. A. Istikomah and P. Jana, "Mathematical Prolem Solving Ability in Apos Modified Learning Model ( M-APOS )," $J$. Phys. Conf. Ser., vol. 1254, no. 2019, pp. 1-6, 2019.

[4] R. Silviani, C. M. Zubainur, and M. Subianto, "Kemampuan Berpikir Kreatif Siswa SMP melalui Model Problem Based Learning,” J. Didakt. Mat., vol. 5, no. 1, pp. 27-39, 2018.

[5] S. S. Sugiarti; Dewanti, "PENGARUH PENERAPAN PENDEKATAN PROBLEM BASED LEARNING ( PBL ) DENGAN MODEL PEMBELAJARAN KOOPERATIF TIPE THINK PAIR SHARE (TPS) TERHADAP PENINGKATAN KEMAMPUAN PEMECAHAN MASALAH MATEMATIKA DAN SELF CONFIDENCE,” vol. 8, no. 1, 2018.

[6] S. A. Peranginangin, S. Saragih, and P. Siagian, "Development of Learning Materials through PBL with Karo Culture Context to Improve Students ' Problem Solving Ability and Self-Efficacy," Int. Electron. J. Math. Educ., vol. 14, no. 2, pp. 265-274, 2019.

[7] P. L. Jansson, S., S derstr m, H., Andersson and M. L. Nording, "Implementation of problem-based learning in environmental chemistry.," J. Chem. Educ., vol. 92, no. 12, pp. 2080-2086, 2015.

[8] R. Wahyuni, E. Efuansyah, and S. Sukasno, "Developing Student Worksheet Based on Think-Talk-Write Strategy of Class VIII," Infin. J. Math. Educ., vol. 9, no. 1, pp. 81-92, 2020.

[9] P. Widoretno and N. F. D. B. P, "PENGEMBANGAN LKS DENGAN PEMBELAJARAN BERBASIS MASALAH PADA MATERI DIAGRAM GAYA NORMAL, GAYA LINTANG, DAN MOMEN DI KELAS $X$ TGB 1 SMK NEGERI 1 SIDOARJO,” vol. 3, pp. 44-49, 2014.

[10] E. Sudibyo, A. F. Naini, and W. B. Sabtiawan, "The Effectiveness of Student Worksheet to Train Science," $J$. Penelit. Pendidik. IPA, vol. 4, no. 2, pp. 70-74, 2019.

[11] A. Majid, Perencanaan Pembelajaran Mengembangkan Standar Kompetensi Guru. Bandung: PT Remaja Rosdakarya, 2008.

[12] C. M. Anggraini, K. Warniasih, and P. Jana, "Development of Student Work Sheets Based on Contextual Learning to Facilitate Mathematic Concept Understanding Skill of Junior High School Student 7 th Grade at Triangle Material," Form. J. Ilm. Pendidik. MIPA, vol. 9, no. 1, pp. 1-10, 2019.

[13] I. Agustina, D. Astuti, R. A. Sumarni, and D. L. Saraswati, "Pengembangan Media Pembelajaran Fisika Mobile Learning berbasis Android,” JPPPF, vol. 3, pp. 57-62, 2017.

[14] A. W. Putra, "PENGEMBANGAN MODUL DENGAN PENDEKATAN OPEN ENDED UNTUK MEMFASILITASI PENCAPAIAN LITERASI MATEMATIS,” ISSN, vol. 6, no. 2, pp. 159-168, 2017.

[15] E. Mulyatiningsih, Riset Terapan Bidang Pendidikan dan 
Tekhnik. Yogyakarta: UNY Perss, 2011.

[16] K. Kintoko and P. Jana, "Development of Mathematics Module on the Material of Flat Side Space Development of Mathematics Module on the Material of Flat Side Space Building in DIY Culture-Based .,” J. Phys. Conf. Ser. Pap., vol. 1254, pp. 1-7, 2019.

[17] L. D. Nguyen and S. Suppasetseree, “The Development of an Instructional Design Model on Facebook Based Collaborative Learning to Enhance EFL Students' Writing Skills,” IAFOR J. Lang. Learn., vol. 2, no. 1, 2016.

[18] E. KOC, "Design and Evaluation of a Higher Education Distance Eap Course by Using the ADDIE Model,” Electron.
J. Soc. Sci., vol. 19, no. 73, pp. 523-531, 2020.

[19] D. A. S. C. Donna Avianty1, "PENGEMBANGAN MULTIMEDIA INTERAKTIF BERBASIS MASALAH UNTUK MENDAYAGUNAKAN KEMAMPUAN BERPIKIR TINGKAT TINGGI PADA SISWA SEKOLAH DASAR,” ISSN, vol. 7, no. 2, pp. 237-242, 2018.

[20] I. R. A. S. Fendi Susanto1), "PENGEMBANGAN PERANGKAT PEMBELAJARAN MODEL KOOPERATIF TIPE NHT DENGAN STRATEGI PEMECAHAN MASALAH (PROBLEM SOLVING) SISTEMATIS BAGI PESERTA DIDIK SMP DI KABUPATEN PRINGSEWU,” ISSN, vol. 6, no. 3, 2017. 